\title{
Effects of egg parts addition on colour, textural and sensory properties of block-type melted cheese: a case study
}

\author{
Mustafa ÇAVUŞ ${ }^{\star *}$ (D), Bayram YURT², Hasan CANKURT ${ }^{1}$
}

\begin{abstract}
In this study, by the addition of chicken egg the production possibilities of the block-typed processed cheese and the changes that occur on the various properties due to the storage of the produced cheese were analyzed. Before the blanching, three different parts of the egg; albumen, yolk and whloe egg were added to the processed cheese formulation. The cheeses were analyzed on the first, 15th, 30th and 60th days. The physico-chemical, textural and sensory characteristics of the cheese samples were tested. It was determined out of the obtained results that the use of the chicken egg was decreased in the values of $\mathrm{L}^{*}, \mathrm{a}^{*}$ and $\mathrm{b}^{\star}$. According to the texture results, the control sample stood out to be the cheese type that has the highest hardness. Of all the parameters, the sample with yolked-cheese got the highest point according to the results of the sensory evaluation. The use of yolk affected positively both the structure and the appearance. At the end of this study, it is found out that the use of chicken egg in the production of the block-typed processed cheese did not cause any drawback in terms of both production process, shelf life and from the sensory point.
\end{abstract}

Keywords: block type processed cheese; chicken egg; melting salt; storage.

Practical Application: Effects of egg parts addition on block-type melted cheese.

\section{Introduction}

Cheese is a milk product that is consumed preferably as fresh or mature and generally obtained by coagulating whole milk, low-fat milk or skim milk with appropriate proteolytic enzymes known as rennet and/or lactic acids, separating the whey, shaping the curd and salting in the last step (Üçüncü, 2008). Melted cheese is produced through pasteurisation of curd, one or more types of cheese directly or a mixture obtained by adding milk products such as milk powder, whey, butter and cream into such products when necessary, at high temperatures with emulsifying salts. It can be sliceable or spreadable (Anonymous, 2014).

The dairy industry has to renew itself to stimulate consumer interest. In order to guide the development of dairy products in the food industry, it is necessary to determine the needs and expectations of different consumer groups. It is the consumer itself that determines the parameters of product quality (Busse \& Siebert, 2018; Hovart et al., 2019). The appearance and taste of the food are not the only factors affecting the food choice of the consumer. In addition to these, the nutritional properties, composition, safety, trade and price of the product have a significant influence on purchase (F.R. Torres et.al., 2020).

There are some considerations that make the production of melted cheese important. These considerations, namely, high nutritional value, giving an opportunity of re-evaluation to cheeses that are deformed or have damaged packages but maintain their sensory properties, ease of packaging thanks to smaller packages, having spreadable types, and possibility to use different types and various ratios of raw material in the production are the advantages of this product. In addition, as it is cooked at high temperature, it has longer shelf life (Kiermeier \& Lechner, 1973; Turhan, 1993).

Since there is a positive relationship between the excessive consumption of sodium mineral in foods and hypertension, osteoporosis, kidney stones and cardiovascular diseases, various studies are carried out to reduce sodium in foods (Ayyash \& Shah, 2011). Sodium reduction studies in the cheese sector have been very difficult for manufacturers because the sodium in cheese improves the texture of the product and adds flavor to the product (Cruz et al., 2011). Therefore, new methods such as $\mathrm{NaCl}-\mathrm{KCl}$ mixture have been tried and used in various cheeses without any negative effect on cheese quality (Silva et al., 2018).

Consumption of probiotic-enriched dairy products is very beneficial for health, including anti-hyperglycemic activity. This benefit varies depending on the starter culture and dairy product used (Grom et al., 2020).

Although cheeses are generally classified according to their high fat content, no link has been found between cheese consumption and cardiovascular disease (Verruck et al., 2019). The nutritional properties of cheese are due to casein proteins, which occurs during cheese ripening and during digestion. Due to its rich nutritional content, cheese is a functional dairy product that is consumed not only for energy, but also because 
it benefits diseases such as hypertension, diabetes, obesity and digestive problems (Hjerpsted \& Tholstrup, 2016). In the treatment of some diseases such as hypertension, it has been revealed that, in addition to medications, reducing the consumption of saturated fat and sodium and increasing the consumption of potassium, calcium and fiber foods positively affects blood pressure (Martyn-Nemeth et al., 2016).

Egg, which is not only consumed alone but also increases nutritional value of the accompanying food and therefore is largely used in nutrition, is commonly used as additive for its emulsifying, humectant, leavening, colouring, flavouring and thickening properties in the processing of many food products as well as for its dough forming, thickening, binding and ingredient constituting properties in terms of baking quality (Tayar \& Şen, 1996; Surai \& Sparks, 2001).

Carotenoids are synthesized only in plants and mixed with animal tissues only through feedstuff and nutrition. In addition, they are modified and stored in animal tissues. In particular, egg yolk colour occurs by the help of these modified carotenoids (Tokuşoğlu, 2006). Lutein is the active pigment of egg yolk as it provides approximately $70 \%$ of its colour alone. Another important pigment besides lutein is zeaxanthin. Apart from these, components that are effective in the colouring of egg yolk are respectively carotene, canthaxanthin, cryptoxanthin and capsanthin (Hammond et al., 1997). There is no colour standard for melted cheese as different types of cheese are used in the production. For that reason, carotenoids in egg yolk have been used to ensure a colour standard for melted cheese.

In the present study, effect of whole or different part of egg on colour, textural and sensorial properties of melted cheese was examined and compared to that of control sample during 60 day-storage period.

\section{Material and Methods}

\subsection{Materials}

Cow's milk was used in the production of cheese. Rennet, kasharstarter cultures and calcium chloride were bought from a firm in Konya (İntermak A.Ş.). Eggs were bought from an egg company that is operating in Kayseri market (Tarım Gida ve Yumurtacılık Ltd. Şti.). Melting salts containing phosphate and citrate as emulsifying salts in their structure were preferred. Among emulsifying salts known as Kasomel salts in the market, Kasomel 3112 at the rate of $0.3 \%$ and Kasomel 2185 at the rate of $0.7 \%$ were added in cheese curd during blanc.

\subsection{Sample preparation}

Preparation process of samples were schematized in Figure 1.

\subsection{Colour parameters}

Colours of cheeses were measured as per Doğan (2002). Cheeses were scanned on HP Scanjet $4050 \mathrm{C}$ scanner and the images were stored in JPG format. $\mathrm{L}^{\star}, \mathrm{a}^{*}$ and $\mathrm{b}^{\star}$ values of these images were detected by using 'Lab Color Mod' (16 Bits/channel) settings.

\subsection{Textural properties}

Textural properties of cheese samples were determined by using a texture measurement instrument, i.e. TA. XT Plus Texture Analyser, as per the method defined in Ahmed et al. (2005). Samples to be analysed were diced in $2.0 \mathrm{~cm}$. A $2 \mathrm{~cm}$ spherical probe was used for pressure. Also, in compression process, $25 \%$ of original sizes of samples were compressed with a compression rate of $1 \mathrm{~mm} / \mathrm{s}$ by setting total duration of processing as 10 seconds and using a $30 \mathrm{~kg}$ load cell. Two consecutive compressions were performed according to texture profile analysis technique. Texture profile of samples were determined by measuring texture profile analysis parameters, namely, hardness, resilience, cohesiveness, adhesiveness, gumminess, springiness and chewiness.

\subsection{Sensorial properties}

Sensory analyses of block-type melted cheese were performed according to scoring method by 7 experienced panellists. First of all, scores were established according to sensory quality criteria of cheeses with the trained panellists. Cheese samples were taken out of the refrigerator and served to the panellists in portions of 15-20 g with bread and water. The panellists were asked to evaluate cheeses in terms of quality characteristics of appearance, texture, taste and overall impression, and mark defect(s) that caused lower scores (Koca, 2002).

\subsection{Statistical analysis}

Results of colour, textural and sensorial analysis in the study were evaluated with one-way analysis of variance (one-way ANOVA) by using JMP Pro software package. Difference between significant averages as a result of analysis was tested at a level of $p<0.05$ via Tukey's multiple comparison test (Abdi \& Williams, 2010).

\section{Results and discussion}

\subsection{Colour measurements}

Colour parameters including $\mathrm{L}^{\star}, \mathrm{a}^{\star}$ and $\mathrm{b}^{\star}$ values of melted cheeses throughout a 60-day storage were given in Table 1. Regarding $1^{\text {st }}$ day results, while the control sample had the highest $\mathrm{L}$ value, sample containing egg yolk had the lowest. On $15^{\text {th }}$ day sample containing whole egg had the highest L value among the samples.

Among the samples, control group had the highest $\mathrm{L}^{*}$ value while sample containing egg white had the lowest. Since control group cheeses are shinier than other cheeses, they had the highest $L^{*}$ value. Besides, as egg white added cheeses were predominantly yellow, i.e. darker, the lowest $\mathrm{L}^{*}$ value was found in that type of cheese. Johnston \& Darcy (2000) observed that $L^{\star}$ value of Mozzarella cheese, which was stored at $4 \mathrm{C}$, showed a decrease during ripening. In other studies on cheese types similar to block-type melted cheese and kasseri, $L^{*}$ values decreased with ripening (Frrat, 2006; Gülter, 2011; Cankurt, 2015).

Among the cheeses, sample containing egg yolk had the highest $\mathrm{a}^{\star}$ value with -4.85 while the sample containing egg white had the lowest as -7.09 . Although $\mathrm{a}^{*}$ value demonstrated a wavy decrease in melted cheeses, an increase compared to the first day 
was detected in all samples at the end of storage. Martley \& Michel (2001) observed mean a value as -2.10 in Cheddar cheese.

Similarly to $\mathrm{L}^{*}$ and $\mathrm{a}^{*}$ values, $\mathrm{b}^{*}$ value differed greatly since the first day and a similar situation continued throughout ripening.
Among the samples at day 1 of ripening process, the lowest $b^{*}$ value 24.254 was measured in control group cheeses while the highest value 39.120 was in melted cheese with egg yolk, as expected.

\section{BLOCK-TYPE MELTED CHEESE PRODUCTION}

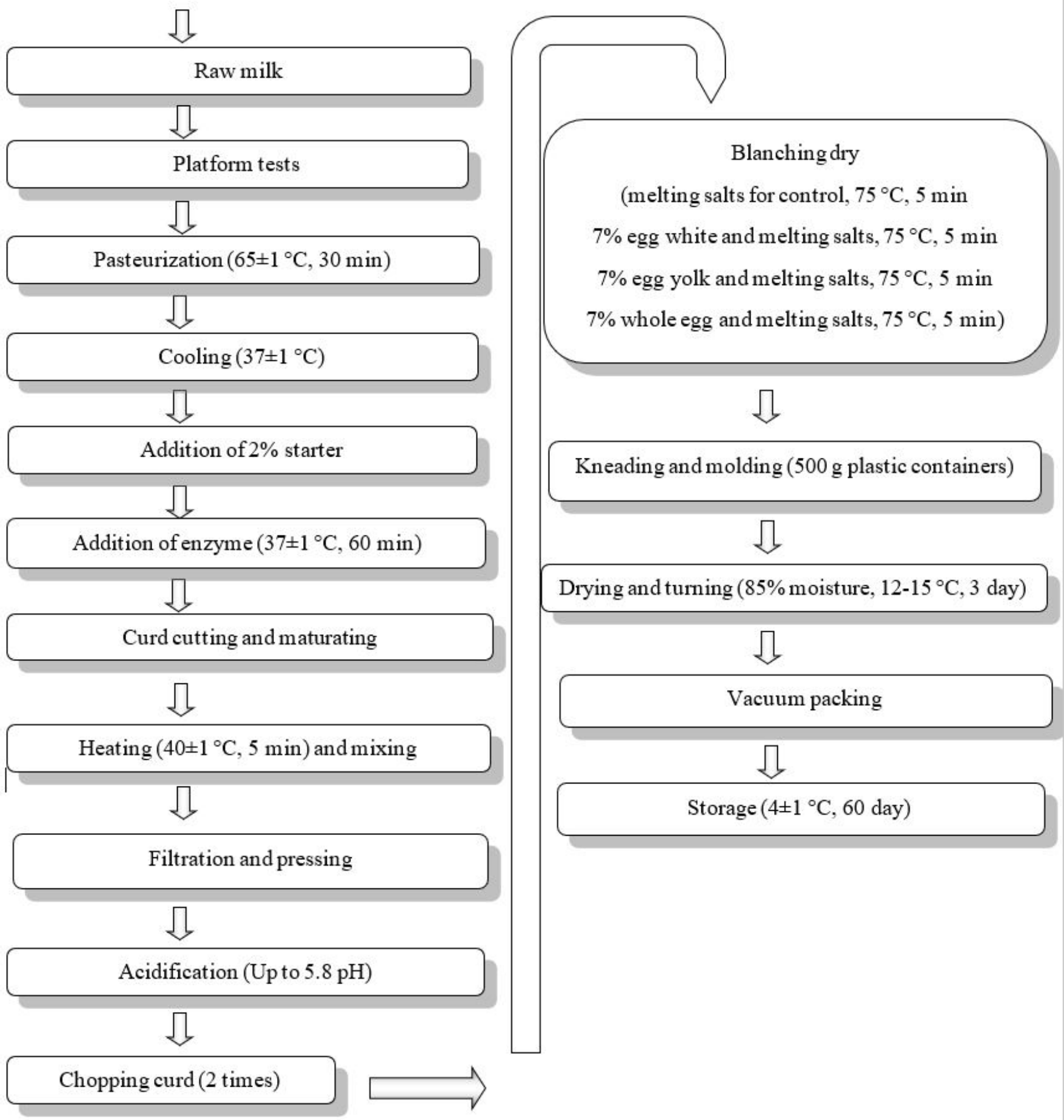

Figure 1. Flow chart of block-type melted cheese production. 
Although $L^{*}$ value of cheeses in our study decreased with ripening, they had higher $\mathrm{L}^{*}$ value than the results in other studies. The reason may depend on several factors. These factors may include pasteurisation temperature applied on the final product, drying conditions and duration of product, salt amount used and packaging type of product. For instance, it is expectable that vacuum-packed products are whiter than cheeses ripened without cover.

\subsection{Textural properties}

Hardness is about moisture and salt-to-moisture ratio of cheese. Softening increases when the amount of total dry matter in cheese decreases and hardness increases when saltto-moisture ratio shows an increase. In addition, fat, protein content and $\mathrm{pH}$ value also have an impact on hardness values of product (Kaya, 2002).

Among all cheese samples, control group cheeses had the highest hardness value with $8059.79 \mathrm{~N}$ while the lowest value was measured in cheeses with egg white with $2367.6 \mathrm{~N}$. The reason that control group cheeses had the highest hardness value may result from having a high level of total dry matter. However, the reason that yolk added cheese was softer than control cheese could be due to lecithin in yolk acting as emulsifier. Among other types of cheese, the reason that the softest one had egg white was the content of $88 \%$ water in its structure (United States Department of Agriculture, 2000). According to the reports in literature (Kaya, 2002), softening increases when the amount of total dry matter in cheese decreases and hardness increases when salt-to-moisture ratio shows an increase. In this respect, the fact that egg white added cheese has the lowest hardness may be partially attributed to having the highest moisture content. Dabour et al. (2006) determined in a study on Cheddar cheese that loss of moisture during ripening increased the hardness value. Solak (2013) stated that hardness values of block-type melted cheeses produced at different $\mathrm{pH}$ values by using different types of cheese increased at the end of three-month ripening compared to the values at day 1 . While results of this study bear resemblance to ours, cheeses in our study had higher hardness values. We can relate increasing hardness value of cheese during storage to the decrease in $\mathrm{pH}$ value (Thapa \& Gupta, 1992).
Among the cheeses, sample containing egg white had the highest Springiness value with 0.87 while the sample containing egg yolk had the lowest as 0.80 . This decrease seen in all cheeses during ripening proces was statistically significant $(\mathrm{p}<0.05)$. Cankurt (2015) stated that springiness values of block-type melted cheeses demonstrated a wavy decrease and values of all samples decreased at the end of ripening compared to day 1.

As seen in Table 2, gumminess values of cheeses varied from 1818.88 to 3571.62 at the beginning of storage while ranged between 3475.44 and 5349.85 with an increase at the end of ripening. While control group had the highest gumminess value, the lowest value was measured in sample containing egg white. However, sample containing egg yolk and sample containing whole egg received close values averagely. Gumminess and hardness values changed in parallel. This similarity stems from calculating gumminess value by multiplying cohesiveness and hardness values. Solak (2013) reported that gumminess values of block-type melted cheeses produced at different $\mathrm{pH}$ values by using different types of cheese increased at the end of 90 day storage.

While cohesiveness values of cheeses ranged between 0.73 and 0.77 at the beginning of storage, they showed a tendency of decrease and ranged from 0.66 to 0.73 at the end of ripening. Among all cheese samples, egg white and control group added cheese had the highest cohesiveness value while the lowest value was observed in cheeses with control. Koca (2002) reported that increasing fat content of cheeses caused a decrease in cohesiveness value. Yaşar (2008) stated that cohesiveness values of cheeses produced within the scope of doctoral examination decreased depending on duration of ripening.

Control sample had the highest chewiness value among the melted cheeses On the other hand, the lowest value was observed in egg white added cheeses. Chewiness and gumminess values showed parallel changes. The reason of this similarity stems from obtaining chewiness value by multiplying gumminess and resilience values. The increase seen in all melted cheeses during storage was considered statistically significant $(\mathrm{p}<0.05)$. This increase in chewiness value may be due to increased gravitational force between molecules by the increase of interaction between proteins and other compounds in the structure of cheese.

Table 1. Colour Parameters of Samples during Storage.

\begin{tabular}{|c|c|c|c|c|c|}
\hline & & Egg White & Control & Egg Yolk & Whole Egg \\
\hline \multirow[t]{3}{*}{$1^{\text {st }}$ Day } & $\mathrm{L}$ & $94.75 \pm 0.35^{\mathrm{aA}}$ & $96.75 \pm 0.27^{\mathrm{aA}}$ & $90.70 \pm 0.96^{\mathrm{bAB}}$ & $95.94 \pm 0.57^{\mathrm{aAB}}$ \\
\hline & $\mathrm{a}$ & $-6.80 \pm 0.046^{\mathrm{bB}}$ & $-6.53 \pm 0.01^{\mathrm{bB}}$ & $-5.39 \pm 0.27^{\mathrm{aB}}$ & $-7.02 \pm 0.04^{\mathrm{bB}}$ \\
\hline & $\mathrm{b}$ & $24.62 \pm 0.80^{\mathrm{bA}}$ & $24.25 \pm 0.75^{\mathrm{bA}}$ & $39.12 \pm 1.91^{\mathrm{aA}}$ & $28.37 \pm 1.98^{\mathrm{bA}}$ \\
\hline \multirow[t]{3}{*}{$15^{\text {th }}$ Day } & $\mathrm{L}$ & $93.25 \pm 0.10^{\mathrm{abA}}$ & $91.54 \pm 0.17^{\mathrm{abB}}$ & $92.07 \pm 1.77^{\mathrm{bAB}}$ & $94.41 \pm 0.19^{\mathrm{aB}}$ \\
\hline & $\mathrm{a}$ & $-6.24 \pm 0.004^{\mathrm{bA}}$ & $-6.35 \pm 0.22^{\mathrm{bB}}$ & $-4.85 \pm 0.27^{\mathrm{bA}}$ & $-5.99 \pm 0.01^{\mathrm{bA}}$ \\
\hline & $\mathrm{b}$ & $24.55 \pm 0.16^{\mathrm{bA}}$ & $22.68 \pm 0.62^{\mathrm{bA}}$ & $37.12 \pm 1.78^{\mathrm{aAB}}$ & $28.02 \pm 2.21^{\mathrm{bA}}$ \\
\hline \multirow[t]{3}{*}{$30^{\text {th }}$ Day } & $\mathrm{L}$ & $86.61 \pm 4.53^{\mathrm{aB}}$ & $95.71 \pm 0.12^{\mathrm{aA}}$ & $90.19 \pm 0.55^{\mathrm{aB}}$ & $96.06 \pm 0.67^{\mathrm{aA}}$ \\
\hline & $\mathrm{a}$ & $-7.09 \pm 0.09^{c \mathrm{C}}$ & $-5.88 \pm 0.10^{\mathrm{bA}}$ & $-5.34 \pm 0.04^{\mathrm{aAB}}$ & $-5.97 \pm 0.15^{\mathrm{bA}}$ \\
\hline & $\mathrm{b}$ & $24.33 \pm 0.04^{\mathrm{cA}}$ & $23.64 \pm 0.20^{\mathrm{cA}}$ & $34.86 \pm 0.09^{\mathrm{aB}}$ & $28.55 \pm 0.41^{\mathrm{bA}}$ \\
\hline \multirow[t]{3}{*}{$60^{\text {th }}$ Day } & $\mathrm{L}$ & $92.87 \pm 0.99^{\mathrm{bA}}$ & $95.91 \pm 0.11^{\mathrm{aA}}$ & $92.68 \pm 0.17^{\mathrm{bA}}$ & $88.20 \pm 0.69^{c \mathrm{c}}$ \\
\hline & $\mathrm{a}$ & $-6.20 \pm 0.07^{\mathrm{cA}}$ & $-5.81 \pm 0.03^{\mathrm{bA}}$ & $-4.92 \pm 0.16^{\mathrm{aAB}}$ & $-6.16 \pm 0.05^{\mathrm{bcA}}$ \\
\hline & $\mathrm{b}$ & $24.35 \pm 0.19^{\mathrm{cA}}$ & $22.93 \pm 0.75^{\mathrm{cA}}$ & $37.34 \pm 0.60^{\mathrm{aAB}}$ & $26.57 \pm 0.94^{\mathrm{bA}}$ \\
\hline
\end{tabular}


Table 2. Textural properties of samples during storage

\begin{tabular}{|c|c|c|c|c|c|c|c|c|}
\hline & & Hardness & Adhesiveness & Springiness & Cohesiveness & Gumminess & Chewiness & Resilience \\
\hline \multirow[t]{4}{*}{ 1st Day } & Egg White & $2367.60 \pm 362.97^{\mathrm{dC}}$ & $-0.52 \pm 0.43^{\mathrm{aA}}$ & $0.87 \pm 0.01^{\mathrm{aA}}$ & $0.77 \pm 0.01^{\text {aA }}$ & $1818.88 \pm 304.94^{\mathrm{cC}}$ & $1575.26 \pm 271.38^{\mathrm{cD}}$ & $0.46 \pm 0.01^{\mathrm{aA}}$ \\
\hline & Control & $4650.50 \pm 447.13^{\mathrm{aC}}$ & $-0.61 \pm 0.26^{\mathrm{aA}}$ & $0.86 \pm 0.01^{\mathrm{aA}}$ & $0.77 \pm 0.01^{\mathrm{aA}}$ & $3571.62 \pm 327.93^{\mathrm{aB}}$ & $3082.53 \pm 268.95^{\mathrm{aC}}$ & $0.46 \pm 0.01^{\mathrm{aA}}$ \\
\hline & Egg Yolk & $3018.70 \pm 278.10^{\mathrm{bD}}$ & $-0.66 \pm 0.49^{\mathrm{aA}}$ & $0.83 \pm 0.02^{\mathrm{bA}}$ & $0.73 \pm 0.05^{\mathrm{bA}}$ & $2191.17 \pm 264.02^{\mathrm{bC}}$ & $1820.49 \pm 197.93^{\mathrm{bC}}$ & $0.43 \pm 0.03^{\mathrm{bA}}$ \\
\hline & Whole Egg & $2633.01 \pm 254.86^{\mathrm{cC}}$ & $-0.52 \pm 0.27^{\mathrm{Aa}}$ & $0.86 \pm 0.01^{\mathrm{aA}}$ & $0.75 \pm 0.02^{\mathrm{abA}}$ & $1974.89 \pm 182.30^{\mathrm{cC}}$ & $1694.87 \pm 149.5^{\mathrm{bcC}}$ & $0.45 \pm 0.02^{\mathrm{aA}}$ \\
\hline \multirow[t]{4}{*}{ 15th Day } & Egg White & $3291.91 \pm 395.3^{\mathrm{dB}}$ & $-1.08 \pm 0.41^{\mathrm{aAB}}$ & $0.83 \pm 0.00^{\mathrm{aB}}$ & $0.7115 \pm 0.01^{\mathrm{abB}}$ & $2342.07 \pm 281.49^{\text {св }}$ & $1936.85 \pm 240.19^{\mathrm{cC}}$ & $0.38 \pm 0.00$ ав \\
\hline & Control & $3780.90 \pm 993.77^{\mathrm{cD}}$ & $-1.01 \pm 1.38^{\mathrm{aA}}$ & $0.83 \pm 0.02^{\mathrm{aC}}$ & $0.72 \pm 0.02^{\mathrm{aB}}$ & $2730.13 \pm 727.48^{\mathrm{bC}}$ & $2269.20 \pm 652.27^{\mathrm{bD}}$ & $0.39 \pm 0.03^{\mathrm{aB}}$ \\
\hline & Egg Yolk & $4119.14 \pm 121.18^{\mathrm{bC}}$ & $-1.87 \pm 0.65^{\mathrm{aB}}$ & $0.80 \pm 0.01^{\mathrm{bC}}$ & $0.70 \pm 0.01^{\mathrm{bAB}}$ & $2876.03 \pm 111.33^{\mathrm{bB}}$ & $2297.42 \pm 102.83^{\text {bB }}$ & $0.38 \pm 0.01^{\mathrm{aB}}$ \\
\hline & Whole Egg & $4485.57 \pm 663.43^{\mathrm{aB}}$ & $-1.34 \pm 0.48^{\mathrm{aB}}$ & $0.82 \pm 0.01^{\mathrm{aC}}$ & $0.7141 \pm 0.01^{\mathrm{aC}}$ & $3204.96 \pm 481.22^{\mathrm{aB}}$ & $2619.42 \pm 417.55^{\mathrm{aB}}$ & $0.39 \pm 0.01^{\mathrm{aB}}$ \\
\hline \multirow[t]{4}{*}{ 30th Day } & Egg White & $4921.78 \pm 84.55^{\mathrm{bA}}$ & $-1.53 \pm 0.53^{\text {аАв }}$ & $0.84 \pm 0.01^{\mathrm{aB}}$ & $0.71 \pm 0.01^{\mathrm{aB}}$ & $3515.90 \pm 60.70^{\mathrm{bA}}$ & $2945.56 \pm 46.82^{\mathrm{bcA}}$ & $0.33 \pm 0.01^{\mathrm{cC}}$ \\
\hline & Control & $6950.69 \pm 155.85^{\mathrm{aB}}$ & $-2.76 \pm 0.59^{\text {ьв }}$ & $0.81 \pm 0.01^{\mathrm{bD}}$ & $0.69 \pm 0.01^{\mathrm{bC}}$ & $4815.15 \pm 166.72^{\mathrm{aA}}$ & $3909.89 \pm 157.23^{\mathrm{aB}}$ & $0.32 \pm 0.01^{\mathrm{dC}}$ \\
\hline & Egg Yolk & $5080.12 \pm 549.39^{\text {вв }}$ & $-1.82 \pm 0.55^{\mathrm{aB}}$ & $0.81 \pm 0.01^{\mathrm{bBC}}$ & $0.69 \pm 0.02^{\mathrm{bB}}$ & $3503.09 \pm 413.19^{\mathrm{bA}}$ & $2820.77 \pm 330.55^{\mathrm{cA}}$ & $0.37 \pm 0.01^{\mathrm{bB}}$ \\
\hline & Whole Egg & $4998.68 \pm 825.63^{\mathrm{bA}}$ & $-1.18 \pm 0.28^{\mathrm{aB}}$ & $0.83 \pm 0.01^{\mathrm{aB}}$ & $0.72 \pm 0.01^{\mathrm{aBC}}$ & $3621.69 \pm 585.19^{\mathrm{bA}}$ & $2994.32 \pm 474.65^{\mathrm{bA}}$ & $0.39 \pm 0.01^{\mathrm{aB}}$ \\
\hline \multirow[t]{4}{*}{ 60th Day } & Egg White & $4744.68 \pm 232.17^{\mathrm{bA}}$ & $-2.53 \pm 1.95^{\mathrm{aB}}$ & $0.83 \pm 0.01^{\mathrm{aB}}$ & $0.71 \pm 0.00^{\mathrm{aB}}$ & $3403.95 \pm 186.80^{\mathrm{bA}}$ & $2832.16 \pm 181.81^{\mathrm{bB}}$ & $0.32 \pm 0.01^{\mathrm{bC}}$ \\
\hline & Control & $8059.79 \pm 697.58^{\mathrm{aA}}$ & $-1.49 \pm 0.74^{\mathrm{aA}}$ & $0.84 \pm 0.01^{\mathrm{aB}}$ & $0.66 \pm 0.03^{\mathrm{bD}}$ & $5349.85 \pm 634.80^{\mathrm{aA}}$ & $4503.86 \pm 529.73^{\mathrm{aA}}$ & $0.32 \pm 0.01^{\mathrm{bC}}$ \\
\hline & Egg Yolk & $4853.14 \pm 390.73^{\mathrm{bA}}$ & $-2.25 \pm 0.32^{\mathrm{aB}}$ & $0.81 \pm 0.01^{\text {ьв }}$ & $0.72 \pm 0.01^{\mathrm{aAB}}$ & $3475.44 \pm 305.70^{\mathrm{bA}}$ & $2821.46 \pm 268.93^{\mathrm{bA}}$ & $0.34 \pm 0.01^{\mathrm{aC}}$ \\
\hline & Whole Egg & $4945.53 \pm 1207.87^{\mathrm{bA}}$ & $-2.25 \pm 1.15^{\mathrm{aC}}$ & $0.83 \pm 0.02^{\mathrm{aB}}$ & $0.73 \pm 0.01^{\mathrm{aB}}$ & $3616.40 \pm 828.25^{\mathrm{bA}}$ & $3004.62 \pm 652.87^{\mathrm{bA}}$ & $0.35 \pm 0.01^{\mathrm{aC}}$ \\
\hline
\end{tabular}

\begin{tabular}{|c|c|c|c|c|}
\hline Appearance & $\begin{array}{l}\text { Egg white } \\
4.400 \\
4.300 \\
4.200 \\
4.100 \\
3.000 \\
3.900 \\
3.500 \\
\text { Egg yolk }\end{array}$ & \begin{tabular}{|l|l|} 
Texture \\
\end{tabular} & $\begin{array}{l}\text { Egg white } \\
3.100 \\
3.000 \\
3.600 \\
\text { Egg yolk }\end{array}$ & Control \\
\hline $\begin{array}{l}\text { Taste } \\
\\
\text { Whole Egg }\end{array}$ & $\begin{array}{l}\text { Egg white } \\
4.300 \\
4.200 \\
4.000 \\
3.900 \\
3.00 \\
3.700 \\
3.600\end{array}$ & Whole Egg & $\begin{array}{l}\text { Egg white } \\
4.200 \\
4.100 \\
4.000 \\
3.900 \\
3.800 \\
3.700 \\
3.600 \\
3.500 \\
3.400\end{array}$ & Control \\
\hline
\end{tabular}

Figure 2. Sensorial Properties of Samples in $1^{\text {st }}$ day. 


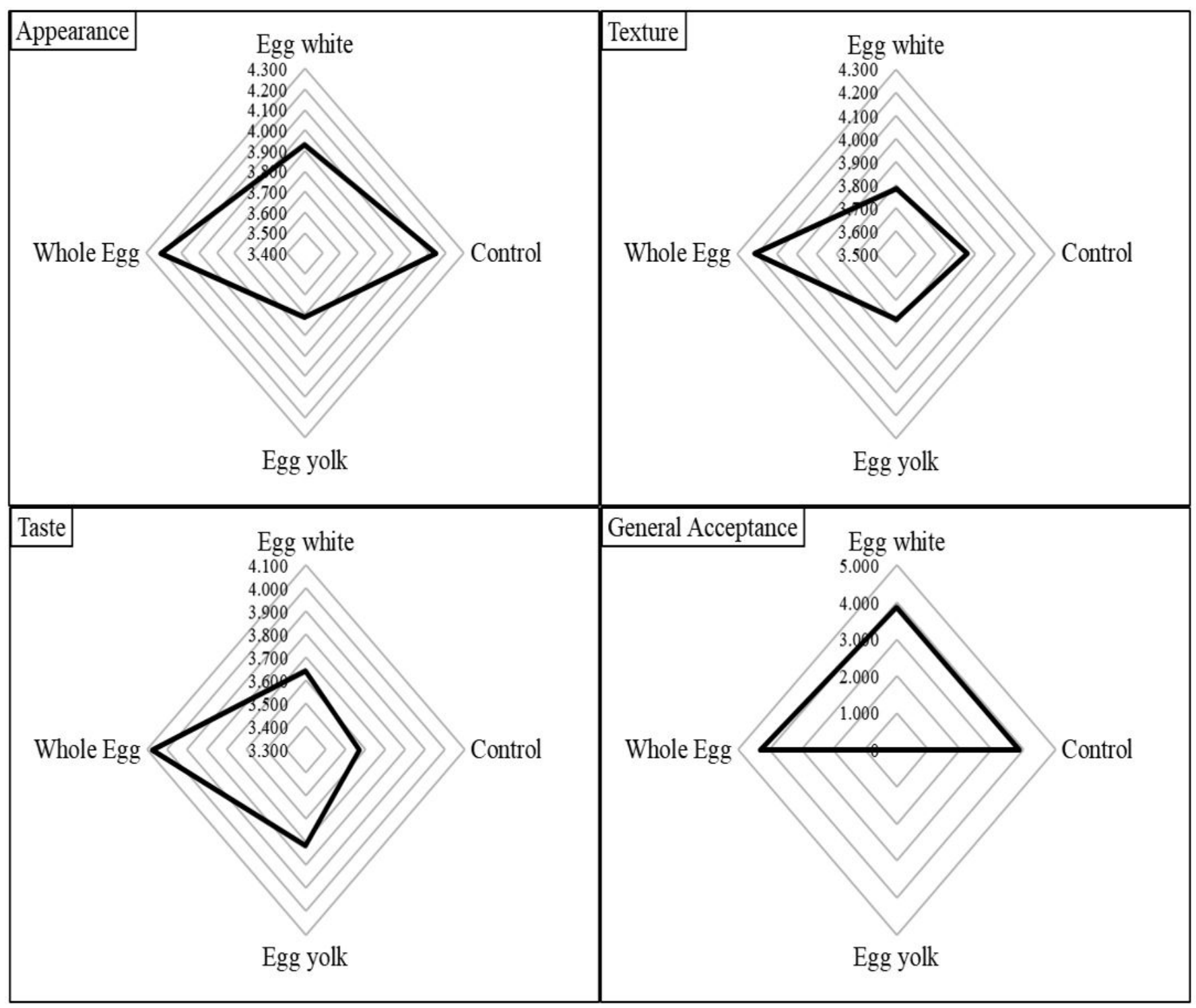

Figure 3. Sensorial Properties of Samples in $15^{\text {th }}$ day.

It is seen that adhesiveness value, which was measured as -0.52 in all cheeses at the beginning of storage, increased four times to be -2.76 on the last day of ripening. The increase in adhesiveness value is thought to stem from biochemical events, proteolysis and moisture content in cheese. Additionally, as dry matter amount in cheese decreases, its adhesiveness value increases (Emmons et al., 1980). Antoniou et al. (2000) stated that high rate of proteolysis in cheese increased adhesiveness value of cheese. In a study on Mozzarella cheese, Dimitreli \& Thomareis (2007) reported that textural properties except for adhesiveness depended on the increase of protein amount.

Among the cheeses, sample containing egg white and control had the highest Resilience value with 0.46 at first day, while the sample containing egg white and control had the lowest as 0.32. last day. Solak (2013) reported that resilience values of block-type melted cheeses produced by them were influenced by changes during ripening. Resilience values of all cheeses we produced within the scope of our research including control cheese decreased during ripening period and this decrease was considered statistically very significant $(\mathrm{p}<0.05)$.

\subsection{Sensorial properties}

Sensory analysis methods based on consumer perception are always popular around the world (Varela \& Ares, 2012). Sensory classification methods have always been effective in methods used for different situations (Lê et al., 2016). The classification methods of foods determine the sensory methods that can be applied in the certification and registration of the Geographical Indication of Origin (Rodrigues et al., 2020). The classification process is a simple tool that sorts a large number of samples used to obtain similar data (Chollet et al., 2013; Courcoux et al., 2014).

Among the cheeses, sample containing egg yolk had the highest appearance value with 4.36 points at first day (Figure 2). The yellow colour from egg yolk was probably the reason why the panellists preferred block-type melted cheese with egg yolk. 
Similarly, as white of egg whitened the cheeses, such cheeses received lower points from the panellists. Solak (2013) stated that appearance scores of block-type melted cheese they produced were low at the end of storage due to proteolytic, enzymatic and microbial changes in cheese during ripening. In another study by Cankurt (2015) on block-type melted cheese, it was reported that appearance scores of melted cheeses were lower at the end of storage compared to day 1 .

Among the cheeses, sample containing whole egg had the highest Texture value with 4.21 points at fifteenth day (Figure 3 ), On the 30th day, the highest texture value was observed in cheese with egg yolk added. (Figure 4).while the sample containing egg white had the lowest as 3.29 points last day. Texture scores increased at day 15 of storage while gradually decreased towards to end of storage. Piacquadio et al. (2001) reported that texture scores of Mozzarella cheeses they produced by using two different salting methods decreased throughout the storage. Schar \& Bosset (2002) stated that texture defects in melted cheeses were caused by physicochemical events occured during ripening phase.
The fact that texture scores of kashar cheeses decreased during ripening was detected by many researchers (Güven et al., 2002; Cürük, 2006; Yaşar, 2008).

Among the cheeses, sample containing whole egg had the highest taste score with 4.21 points at first day, while the sample containing egg white had the lowest as 2.93 points last day (Figure 5).The main reasons that influenced taste improvement of cheese during ripening were various and complex biochemical changes such as proteolysis, lipolysis, lactose fermentation and formation of volatile compounds occured in cheese matrix as well (Kristoffersen, 1985; Lyne, 1995). Fox et al. (1996) and Fox \& McSweeney (1996) reported that components that emerged in consequence of decomposition of para-k-casein were influential in the formation of unique taste and flavour of cheese. Pracquadio et al. (2001) reported that taste scores of Mozzarella cheeses they produced by using two different salting methods decreased as storage time prolonged.

Sensory differences were determined in pasteurized milk and coalho cheese with different number of somatic cells. While

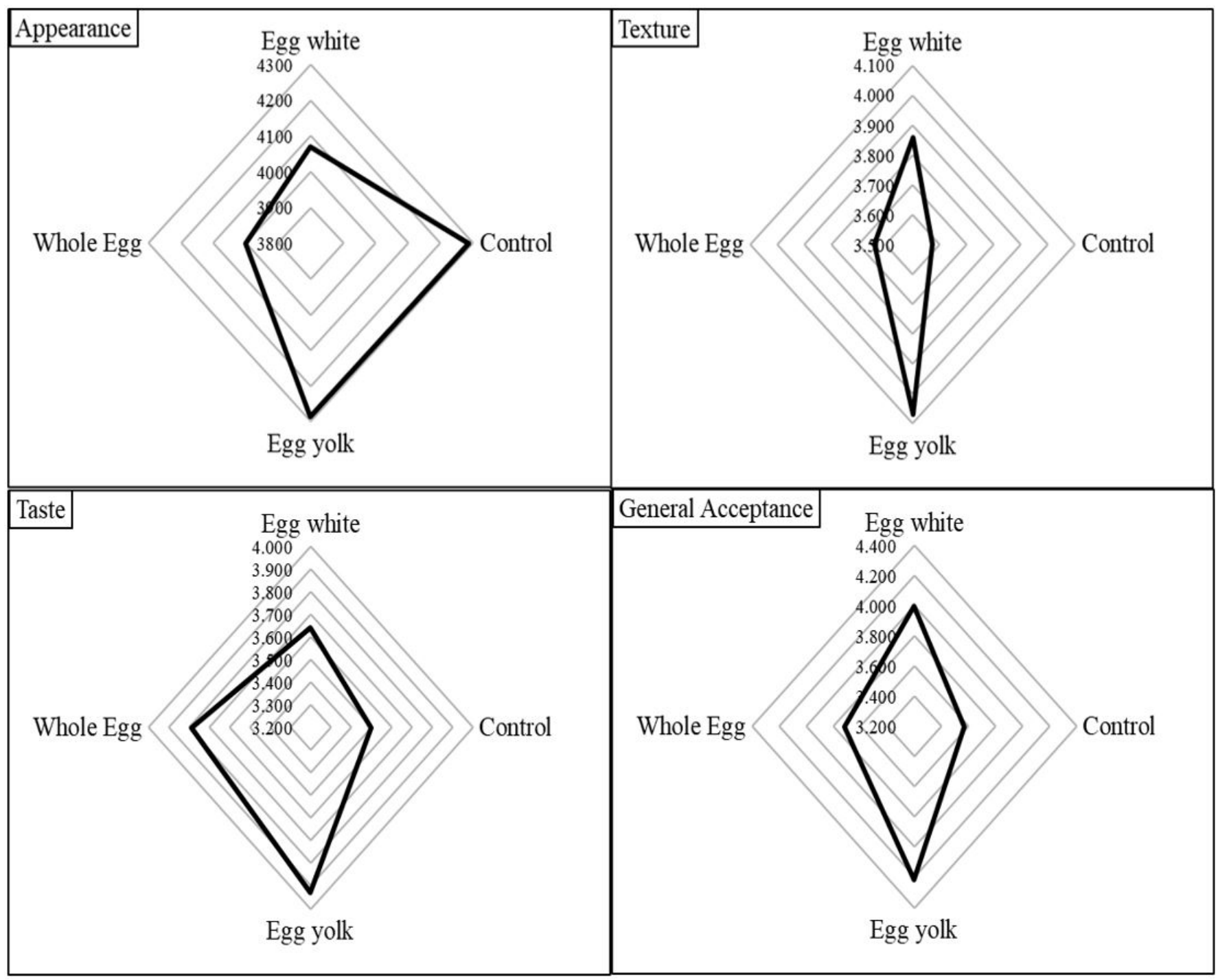

Figure 4. Sensorial Properties of Samples in $30^{\text {th }}$ day. 


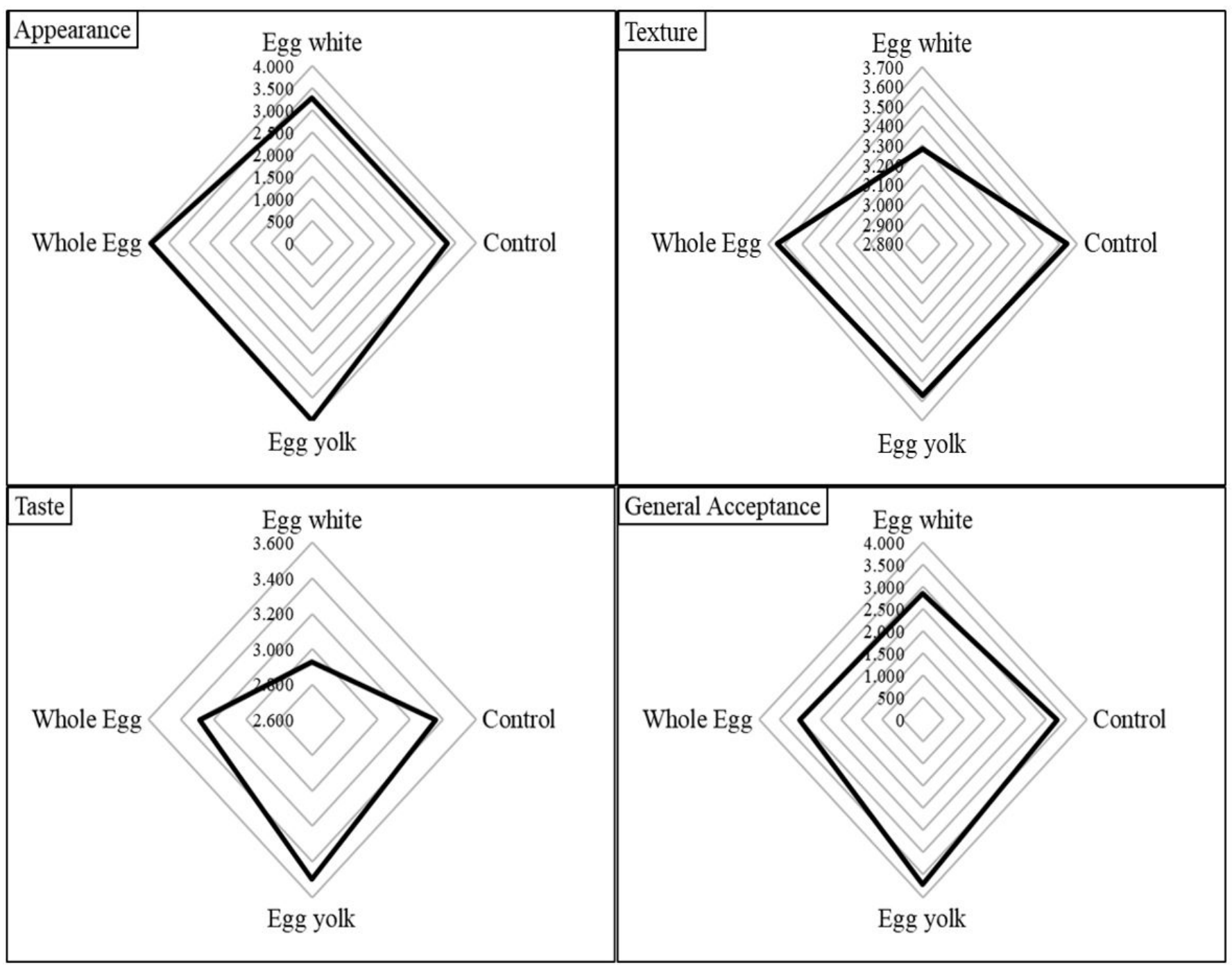

Figure 5. Sensorial Properties of Samples in $60^{\text {th }}$ day.

the two products with a high somatic cell count were sensually undesirable, the low somatic cell count was relatively more appreciated (Bezerra et al., 2020).

Overall impression scores of cheeses we produced in our research ranged between 3.64 and 4.14 at day 1 of storage while ranged from 2.85 to 3.71 at day 60 of ripening. Among all cheeses, egg white added cheeses had the lowest overall impression scores as in appearance and taste characteristics. On the other hand, yolk added cheeses had the highest score as in all other sensory properties. According to scoring by the panellists, the most appreciated cheese was sample containing yolk egg while the least appreciated cheese one was sample containing egg white.

\section{Conclusion}

In this study we examined the possible effects of different egg parts addition on the colour, texture and sensorial properties of melted cheeses. $L^{*}$ values of block-type melted cheeses decreased throughout ripening. Among the samples, control group cheese had the highest $L^{\star}$ value while cheese with egg yolk had the lowest value. The cheese type that had the highest $\mathrm{a}^{\star}$ value was the one with egg white. On the other hand, the lowest value was determined in yolk added cheese. The highest $b^{*}$ value in melted cheeses was observed in the ones with egg yolk as expected at the beginning of storage. This value was maintained until the end of storage. The lowest $b^{\star}$ value was measured in cheeses with egg white.

TPA values of samples, hardness, chewiness and gumminess parameters showed similar changes and the highest values were measured in control group cheeses. And the lowest value was measured in cheese with egg white. However, all cheeses with egg received the highest values in terms of cohesiveness and resilience while the samples produced as control group had the lowest values. Among all samples, cheeses with egg white had the highest springiness value while cheeses with egg yolk had the lowest value of springiness. According to an evaluation of adhesiveness values, it was understood that cheeses with egg yolk had the highest value and those with whole egg had the lowest value. textural properties of all samples, it was seen that control group samples had the highest value of hardness 
throughout ripening. In that regard, the use of egg decreased hardness values of cheeses.

As a result, it was understood that the use of egg in the production of block-type melted cheese would not cause any shortening of shelf life. Based on sensory assessments, it was seen that cheeses that were produced by adding egg yolk were more appreciated than control cheeses. Using different parts of egg in cheese provided these benefits: Overall, addition of egg parts to the melted cheeses affected the final product in a acceptable way.

\section{Acknowledgements}

This study was produced from the data of master thesis conducted by Mustafa ÇAVUŞ.

\section{References}

Abdi, H., \& Williams, L. J. (2010). Tukey's honestly significant difference (HSD) test. Encyclopedia of Research Design, 3, 583-585.

Ahmed, N. H., El Soda, M., Hassan, A. N., \& Frank, J. (2005). Improving the textural properties of an acid-coagulated (karish) cheese using exoploysaccharide producing cultures. Lebensmittel-Wissenschaft + Technologie, 38(8), 843-847. http://dx.doi.org/10.1016/j.lwt.2004.10.001.

Antoniou, K. D., Petridis, D., Raphaelides, S., Ben Omar, Z., \& Kesteloot, R. (2000). Texture assessment of french cheeses. Journal of Food Science, 65(1), 168-172. http://dx.doi.org/10.1111/j.1365-2621.2000. tb15974.x.

Ayyash, M. M., \& Shah, N. P. (2011). The effect of substituting $\mathrm{NaCl}$ with $\mathrm{KCl}$ on Nabulsi cheese: Chemical composition, total viable count, and texture profile. Journal of Dairy Science, 94(6), 27412751. http://dx.doi.org/10.3168/jds.2010-3976. PMid:21605743.

Bezerra, J. D. S., Sales, D. C., Olıveıra, J. P. F. D., Sılva, Y. M. D. O., Urbano, S. A., Lima Júnıor, D. M. D., Borba, L. H. F., Macêdo, C. S., Anaya, K., \& Rangel, A. H. N. (2020). Effect of high somatic cell counts on the sensory acceptance and consumption intent of pasteurized milk and coalho cheese. Food Science and Technology. http://dx.doi.org/10.1590/fst.21620.

Busse, M., \& Siebert, R. (2018). The role of consumers in food innovation processes. European Journal of Innovation Management, 21(1), 2043. http://dx.doi.org/10.1108/EJIM-03-2017-0023.

Cankurt, H. (2015). Bazı bitki su ve uçucu yağların blok tipi eritme peyniri ve beyaz peynirin çeşitli özellikleri üzerine etkisi (Doktora Tezi). Erciyes Üniversitesi Fen Bilimleri Enstitüsü, Kayseri.

Chollet, S., Valentin, D., \& Abdi, H. (2013). Free sorting task. In P. Varela \& G. Ares (Eds.), Novel techniques in sensory characterization and consumer profiling (pp. 207-228). Boca Raton: CRC Press.

Courcoux, P., Faye, P., \& Qannari, E. M. (2014). Determination of the consensus partition and cluster analysis of subjects in a free sorting task experiment. Food Quality and Preference, 32, 107-112. http:// dx.doi.org/10.1016/j.foodqual.2013.05.004.

Cruz, A. G., Faria, J. A. F., Pollonio, M. A. R., Bolini, H. M. A., Celeghini, R. M. S., Granato, D., \& Shah, N. P. (2011). Cheeses with reduced sodium content: Effects on functionality, public health benefits and sensory properties. Trends in Food Science \& Technology, 22(6), 276-291. http://dx.doi.org/10.1016/j.tifs.2011.02.003.

Çukurova Üniversitesi Kütüphanesi. (2014). Sarıçam, Adana: Cukurova Üniversitesi. Retrieved from www.library.cu.edu.tr
Cürük, M. (2006). Kaşar Benzeri Peynirlerin Bazı Özellikleri Üzerine Eritme Tuzu Kullanımının Ve Olgunlaşma Süresinin Etkileri (Doktora Tezi), Çukurova Üniversitesi, Fen Bilimleri Enstitüsü, Gıda Mühendisliği Anabilim Dalı, Adana.

Dabour, N., Kheadr, E. E., Benhamou, E., Fliss, I., \& LaPointe, G. (2006). Improvement of texture and structure of reduced-fat cheddar cheese by exopolysaccharide-producing lactococci. Journal of Dairy Science, 89(1), 95-110. http://dx.doi.org/10.3168/jds.S0022-0302(06)720732. PMid:16357272.

Dimitreli, G., \& Thomareis, A. S. (2007). Texture evaluation of blocktype processed cheese as a function of chemical composition and in relation to is apparent viscosity. Journal of Food Engineering, 79(4), 1364-1373. http://dx.doi.org/10.1016/j.jfoodeng.2006.04.043.

Doğan, İ.S. (2002, 22-24 Mayıs). Bisküvi üretiminde kalite kriteri olarak renk ölçümüne yeni bir yaklaşım. In 7. Gıda Kongresi. Türkiye, Ankara.

Emmons, D. B., Kalab, M., Larmond, E., \& Lowrie, R. J. (1980). Milk gel structure. X. Texture and microstructure in cheddar cheese made from whole milk and from homogenized low-fat milk 1. Journal of Texture Studies, 11(1), 15-34. http://dx.doi.org/10.1111/j.1745-4603.1980. tb00305.x.

Fırat, N. (2006). Çiğ Ve Pastörize Sütten Üretilen Kaşar Peynirlerinin Olgunlaşma Süresince Bazı Mikrobiyolojik, Fiziksel Ve Kimyasal Özelliklerinin Belirlenmesi (Yüksek lisans tezi). Atatürk Üniversitesi Fen Bilimleri Enstitüsü, Gıda Mühendisliği ABD, Erzurum.

Fox, P. F., \& McSweeney, P. L. H. (1996). Proteolysis İn Cheese During Ripening. Food Reviews International, 12(4), 457-509. http://dx.doi. org/10.1080/87559129609541091.

Fox, P. F., O'Connor, T. P., McSweeney, P. L., Guinee, T. P., \& O’Brien, N. M. (1996). Cheese: physical, chemical and nutritional aspects. Advances in Food and Nutrition Research, 39, 163-328. http://dx.doi. org/10.1016/S1043-4526(08)60075-3. PMid:8794552.

Grom, L. C., Rocha, R. S., Balthazar, C. F., Guimarães, J. T., Coutinho, N. M., Barros, C. P., Pimentel, T. C., Venâncio, E. L., Collopy Junior, I., Maciel, P. M. C., Silva, P. H. F., Granato, D., Freitas, M. Q., Esmerino, E. A., Silva, M. C., \& Cruz, A. G. (2020). Postprandial glycemia in healthy subjects: Which probiotic dairy food is more adequate? Journal of Dairy Science, 103(2), 1110-1119. http://dx.doi. org/10.3168/jds.2019-17401. PMid:31785881.

Gülter, S. (2011). Dondurarak kurutulan kaşar peyniri tozlarının özellikleri üzerine peynirin üretim yönteminin, yă̆ oranının ve olgunluğunun depolama sürecindeki etkileri (Yüksek Lisans Tezi). Çukurova Üniversitesi Fen Bilimleri Enstitüsü Gıda Mühendisliği Anabilim Dalı, Adana.

Güven, M., Karaca, O.B., Var, I., Kaçar, A., \& ve Hayaloğlu, A. A., (2002). Antimikrobiyal madde kullanımının ve ambalaj materyalinin olgunlaşma süresince kaşar peynirinin özellikleri üzerine etkisi. Dergisi, 6(1-2), 13-25.

Hammond, B. R. Jr, Wooten, B. R., \& Snodderly, D. M. (1997). Density of the human crystalline lens is related to the macular pigment carotenoids, lutein and zeaksantin. Optometry and Vision Science, 74(7), 499-504. http://dx.doi.org/10.1097/00006324-19970700000017. PMid:9293517.

Hjerpsted, J., \& Tholstrup, T. (2016). Cheese and cardiovascular disease risk: a review of the evidence and discussion of possible mechanisms. Critical Reviews in Food Science and Nutrition, 56(8), 1389-1403. http://dx.doi.org/10.1080/10408398.2013.769197. PMid:25603014.

Hovart, A., Granato, G., Fogliano, V., \& Luning, P. A. (2019). Understanding consumer data use in new product development and the product life cycle in Europeans food firms - an empirical study. Food Quality and Preference, (76), 20-32. 
Johnston, D. E., \& Darcy, P. C. (2000). The Effects Of High Pressure Treatment On İmmature Mozzarella Cheese. Milchwissenschaft. Milk Science International, 55(11), 617-620.

Kaya, S. (2002). Effect of salt on hardness and whiteness of Gaziantep cheese during short-term brining. Journal of Food Engineering, 52(1), 155-159. http://dx.doi.org/10.1016/S0260-8774(01)00098-X.

Kiermeier F., \& Lechner. E. (1973). Milch and Milcherzeugnisse (443 s.). Berlin und Hamburg: Verlag Paul Parey.

Koca, N. (2002). Bazı yağ ikame maddelerinin yağı azaltılmış taze kaşar peynirinin nitelikleri üzerine etkileri (Doktora Tezi). Ege Üniversitesi Fen Bilimleri Enstitüsü, Gıda Mühendisliği ABD, İzmir.

Krıstoffersen, T. (1985). Development of flover İn Cheese. Milchwissenschaft. Milk Science International, 40, 197-199.

Lê, T. M., Husson, F., \& Lê, S. (2016). Digit-tracking: Interpreting the evolution over time of sensory dimensions of an individual product space issued from Napping and sorted Napping. Food Quality and Preference, 47, 73-78. http://dx.doi.org/10.1016/j. foodqual.2015.07.002.

Lyne, J. (1995). İmproving cheese flovour. In 4th Cheese Symposium, National Dairy Products Research Centre, Moorepark (pp. 46-50). Fermoy Co., Cork.

Martley, F. G., \& Michel, V. (2001). Pinkish colouration in cheddar cheese-description and factors contributing to its formation. The Journal of Dairy Research, 68(2), 327-332. PMid:11504395.

Martyn-Nemeth, P., Schwarz Farabi, S., Mihailescu, D., Nemeth, J., \& Quinn, L. (2016). Fear of hypoglycemia in adults with type 1 diabetes: impact of therapeutic advances and strategies for prevention-a review. Journal of Diabetes and Its Complications, 30(1), 167-177. http://dx.doi.org/10.1016/j.jdiacomp.2015.09.003. PMid:26439754.

Pracquadio, P., De Stefano, G., \& Sciancalepore, V. (2001). A no brine method for mozzarella cheese making. Milchwissenschaft. Milk Science International, 56(4)

Rodrigues, J. F., Mangia, B. A., e Silva, J. G., Lacorte, G. A., Coimbra, L. O., Esmerino, E. A., Freitas, M. Q., Pinheiro, A. C. M., \& Cruz, A. G. (2020). Sorting task as a tool to elucidate the sensory patterns of artisanal cheeses. Journal of Sensory Studies, 35(3), e12562. http:// dx.doi.org/10.1111/joss.12562.

Schar, W., \& Bosset, J. O. (2002). Chemical and physico-chemical changes in processed cheese and ready-made fondue during storage: a review. Food Science and Technology, 35, 15-20.
Silva, H. L. A., Balthazar, C. F., Silva, R., Vieira, A. H., Costa, R. G. B., Esmerino, E. A., Freitas, M. Q., \& Cruz, A. G. (2018). Sodium reduction and flavor enhancer addition in probiotic prato cheese: Contributions of quantitative descriptive analysis and temporal dominance of sensations for sensory profiling. Journal of Dairy Science, 101(10), 8837-8846. http://dx.doi.org/10.3168/jds.201814819. PMid:30077456.

Solak, B. B. (2013). Farklı tip peynirler kullanılarak üretilen eritme tipi peynirlerin üretimi esnasında uygulanan işlem parametrelerinin peynirin bazı özellikleri üzerine etkisi (Doktora Tezi). Selçuk Üniversitesi Fen Bilimleri Enstitüsü, Gıda Mühendisliği ABD, Konya.

Surai, P.F. \& Sparks, N.H.C. (2001). Designer eggs: from improvement of egg composition to functional food. Trends in food Science \& Technology, $12,7-16$

Tayar, M., \& Şen, C. (1996). Hayvansal ürünler teknolojisi. Anadolu Üniversitesi.

Thapa, T. B., \& Gupta, V. K. (1992). Changes in the sensoric and rheological characteristics during storage of processed cheese foods prepared with added whey protein concentrates. Indian Journal of Dairy Science, 45, 140-145.

Tokuşoğlu, Ö. (2006). Yumurta: fonksiyonel gida yumurta. (1.Bölüm). Abalı Kurumsal İletişim Dergisi, 4, 6-7.

Turhan, S. (1993). Yağsız sütten işlenmiş taze peynirler ile kaşar peyniri karışımından eritme peyniri üretimi ve üretilen peynirlerin bazı kalite kriterleri üzerinde bir araştırma (Yüksek Lisans Tezi). Ondokuz Mayıs Üniversitesi Fen Bilimleri Enstitüsü, Samsun.

Üçüncü, M. (2008). A'dan Z’ye Peynir Teknolojisi. İzmir: Meta Basım.

United States Department of Agriculture - USDA. (2000). Egg Grading Manual. Washington: USDA.

Varela, P., \& Ares, G. (2012). Sensory profiling, the blurred line between sensory and consumer science. A review of novel methods for product characterization. Food Research International, 48(2), 893-908. http:// dx.doi.org/10.1016/j.foodres.2012.06.037.

Verruck, S., Balthazar, C. F., Rocha, R. S., Silva, R., Esmerino, E. A., Pimentel, T. C., Freitas, M. Q., Silva, M. C., da Cruz, A. G., \& Prudencio, E. S. (2019). Dairy foods and positive impact on the consumer's health. Advances in Food and Nutrition Research, 89, 95-164. http:// dx.doi.org/10.1016/bs.afnr.2019.03.002. PMid:31351531.

Yaşar, K. (2008). Farklı Pıhtılaştırıcı Enzim Kullanımının Ve Olgunlaşma Süresinin Kaşar Peynirinin Özellikleri Üzerine Etkisi (Doktora tezi), Çukurova Üniversitesi Fen Bilimleri Enstitüsü, Adana. 